\title{
Model of a risk-based approach in the organization of control (supervision) in the field of education
}

\author{
Fedor Myshko, Svetlana Titor ${ }^{*}$ \\ State University of Management, 109542, Ryazanskiy prospect, 99, Moscow, Russia
}

\begin{abstract}
The risk-based approach to the organization of state control (supervision) in Russia has been implemented for about six years. At the first stage, this model of control (supervision) was implemented by 25 different supervisory agencies. With the adoption of new legislation regulating control and supervisory activities, the risk-based model has become relevant in the field of education. There is very little experience in implementing a risk-based control (supervision) model. The supervisory agency tried to formulate the principles of such a model in a recommendatory manner to regional supervisory agencies. At the moment, in accordance with the decisions of the authorities, a model of a riskoriented approach to control and supervisory activities has been formed. However, research, incl. foreign experience shows that it can and should be improved. The authors offer their own model of a risk-oriented approach when organizing control (supervision) in the field of education, based on a more differentiated consideration by the criterion of the risk of causing harm to legally protected values.
\end{abstract}

\section{Introduction}

The issue of significant administrative barriers to economic development created by state control (supervision) and municipal control (hereinafter referred to as the control (supervision)) has been raised since the beginning of 2004. The reform in the form of introducing a risk-based approach in the organization of control and supervisory activities began with the introduction in July 2015 of Federal Law of December 26, 2008 No. 294-FZ "On the Protection of the Rights of Legal Entities and Individual Entrepreneurs during State Control (Supervision) and Municipal Control". Art. 8.1. "Application of a riskoriented approach in the organization of state control (supervision)" was introduced. The new rule determined the right to implement risk-based control (supervision) for individual state control and supervisory agencies. The risk-oriented approach to control and supervisory activities was further developed in the newly adopted Federal Law No. 248-FZ of July 31, 2020 "On State Control (Supervision) and Municipal Control in the Russian Federation" (hereinafter - Federal Law No. 248-FZ). The main result of the introduction of a risk-based approach shall be a reduction in the number of inspections and a decrease in

*Corresponding author: setitor@mail.ru 
administrative pressure on business, while increasing the level of protection of legally protected values.

\section{Methodology}

Scientific research is based on the criteria of objectivity, compliance with the truth, is based on the totality of the works of domestic and foreign scientists. The following methods are used in the study process.

The historical method, which implies the consideration of legal reality as the relationship of the past, present and future, is used to analyze development of the legal framework that regulates the risk-based approach when organizing state control (supervision) in the field of education.

The dialectical method, which is based on the following principles: the principle of objectivity, which presupposes the need to consider legal reality as it really is, and not replace ideal ideas; the principle of comprehensiveness, calling for an approach to the study of legal reality from the maximum possible positions, from all sides, and the principle of development aimed at the study of legal reality in motion, were used throughout the study process, namely, in the study of the current and the formation of offers for improving the risk-oriented approach model in the organization of state control (supervision) in the field of education.

General logical methods involved in the work are analysis, synthesis, induction, deduction, and analogy.

The methods of the empirical level, which were also used in the study, include modeling, which in many respects underlies formation of a risk-oriented approach model.

In the study, a comparative legal method was applied, which made it possible to analyze the general and specific in the approach to the control and supervisory activities of two countries - Russia and the Republic of Kazakhstan.

\section{Results of the Study}

At the first stages of introducing a risk-based approach to control and supervisory activities in the field of education, the basic concepts used in reforming control and supervisory activities were determined.

Thus, the risk of harm is understood as the likelihood of occurrence of events, the result of which may be the infliction of harm on values of varying severity protected by law [1].

The list of risk categories or hazard classes used in implementation of a particular type of state control (supervision) includes from 3 to 6 risk categories or from 3 to 6 hazard classes.

Criteria for assigning objects of control (supervision) to risk categories shall consider: - the severity of the potential negative consequences of possible non-compliance by legal entities and individual entrepreneurs with the requirements established by federal laws and other regulatory legal acts of the Russian Federation adopted in accordance with them, laws and other regulatory legal acts of the constituent entities of the Russian Federation,

- the likelihood of non-compliance by legal entities and individual entrepreneurs with mandatory requirements.

Six risk categories and six hazard classes were identified [2].

1. Extremely high risk (hazard class 1) - for federal state control (supervision) - a scheduled inspection is carried out 1 time in the period established by the regulation on the type of federal state control (supervision) or the regulation on licensing a specific type of 
activity; for regional state control (supervision) - a scheduled check is carried out once a year.

2. High risk (hazard class 2) - for federal state control (supervision) - a scheduled inspection is carried out 1 time in the period established by the regulation on the type of federal state control (supervision) or the regulation on licensing a specific type of activity; for regional state control (supervision) - a scheduled inspection is carried out once every 2 years.

3. Significant risk (hazard class 3) - for federal state control (supervision) - a scheduled inspection is carried out 1 time in the period established by the regulation on the type of federal state control (supervision) or the regulation on licensing a specific type of activity; for regional state control (supervision) - a scheduled inspection is carried out once every 3 years.

4. Medium risk (hazard class 4) - for federal state control (supervision) - a scheduled inspection is carried out no more than 1 time during the period established by the regulation on the type of federal state control (supervision) or the regulation on licensing a specific type of activity; for regional state control (supervision) - a scheduled inspection is carried out no more than 1 time in 4 years and at least 1 time in 5 years.

5. Moderate risk (hazard class 5) - for federal state control (supervision) - a scheduled inspection is carried out no more than 1 time during the period established by the regulation on the type of federal state control (supervision) or the regulation on licensing a specific type of activity; for regional state control (supervision) - a scheduled inspection is carried out no more than 1 time in 6 years and at least 1 time in 8 years.

6. Low risk (hazard class 6) - routine inspections are not carried out.

The Federal Service for Supervision in the Field of Education and Science of the Russian Federation (hereinafter - Rosobrnadzor) has developed and sent recommendations to the executive authorities of the constituent entities of the Russian Federation, exercising the delegated powers of the Russian Federation in the field of education, on the selection of educational organizations for inclusion in the annual plan for conducting scheduled inspections (letter dated August 29, 2016 No. 02-343) [3]. The recommendations included the first elements of a risk-based approach when arranging the state control (supervision) in the field of education.

A unified, open and understandable for everyone system for planning on-site inspections was formed, based on the following principles:

- timeliness of response to signs of possible offenses;

- the inevitability of punishment in the case of violations of the legislation in the field of education;

- the validity of the choice of inspection [4].

When planning inspections, it was recommended to analyze:

- data posted in regional information systems on the level of educational achievements of students (results of regional monitoring of the quality of education, state final attestations, all-Russian tests, national and international studies of the quality of education, and other studies);

- data posted in regional information systems on the qualification level of teaching staff (certification results);

- the results of previous inspections;

- information and documents that, in accordance with the legislation of the Russian Federation, must be posted on the official website of the educational organization in the information and telecommunications network Internet;

When forming a plan of inspections and choosing a subject of control, the following criteria shall be taken into account: 
- presence or absence of violations revealed by the results of previously conducted inspections;

- fulfillment of instructions issued based on the results of scheduled and unscheduled inspections;

- presence or absence of citizens' appeals on issues of violation of the legislation of the Russian Federation in the field of education;

- availability of information on violation of the legislation of the Russian Federation in the field of education received from other bodies of state control (supervision), prosecutors, etc.;

- presence of positive dynamics of educational achievements of students, including the results of regional monitoring, studies of the quality of education, state final attestations, all-Russian testing, and etc.;

- innovative activity of educational organizations;

- presence or absence of decisions that have entered into legal force on bringing to administrative responsibility for violations of legislation in the field of education [5].

For the first time, on the basis of these criteria ("risk criteria"), it was offered to form three groups of educational organizations (a prototype of risk categories in the field of education).

First group. Educational organizations:

- showing consistently low results at the level of the regional average, based on the results of regional monitoring, studies of the quality of education, state final attestations, allRussian verification works, and etc.;

- in the activities of which violations of the legislation of the Russian Federation in the field of education were previously revealed, including gross violations of license requirements;

- whose activities have received numerous complaints and appeals.

Second group. Educational organizations:

- showing a stable level of educational achievements of students at the average regional level, based on the results of regional monitoring, studies of the quality of education, state final attestations, all-Russian testing, and etc.;

- in the activities of which there were no gross violations of license requirements.

Third group. Educational organizations:

- showing a consistently high level of educational achievements of students at the level of the average regional, based on the results of regional monitoring, studies of the quality of education, state final attestations, all-Russian testing, and etc.;

- in the activities of which no violations of the legislation of the Russian Federation in the field of education were revealed based on the results of previously conducted inspections, which have high innovative activity;

- where there have been no appeals and complaints from citizens regarding their activities.

The current model for applying the risk-based approach to control and supervisory activities in the field of education (hereinafter - the Model) is regulated by Federal Law of July 31, 2020 No. 248-FZ "On State Control (Supervision) and Municipal Control in the Russian Federation", the Regulation on federal state control (supervision) in the field of education, approved by Decree of the Government of the Russian Federation dated June 25, 2021 No. 997, and is as follows.

The Model is based on harm (damage) risk management which determines:

1. Selection of preventive measures.

2. Selection of control (supervisory) activities.

3. The content of preventive measures.

4. The content of control (supervisory) activities, including the scope of the checked mandatory requirements.

5. Intensity of activities. 
6. Results of activities.

Categories of risk of harm (damage) to legally protected values in the field of education used in the model:

1) high risk category;

2) medium risk category;

3) low risk category.

Criteria for classifying objects of state control (supervision) into risk categories:

1) low risk category - the activities of organizations carrying out educational activities and individual entrepreneurs carrying out educational activities, with the exception of individual entrepreneurs engaged in educational activities directly, for implementation of one or several basic educational programs that have state accreditation of educational activities (with the exception of educational programs for preschool education, basic vocational training programs), and (or) additional educational programs, as well as educational programs aimed at training ministers and religious personnel of religious organizations;

2) medium risk category - the educational activities of controlled persons in presence of an appeal (complaint, statement) recognized as justified based on the results of consideration by the Federal Service for Supervision of Education and Science or the executive authorities of the constituent entities of the Russian Federation exercising the powers of state control delegated by the Russian Federation ( supervision), from individuals and legal entities, including individual entrepreneurs, state and municipal bodies and their officials, the media, on the facts of violation by the controlled person of mandatory requirements and (or) execution of decisions taken as a result of control (supervisory) activities, during the calendar year preceding the date of the decision to classify the object of federal state control (supervision) in the field of education to a certain category of risk;

3) medium risk category - educational activities of controlled persons in presence of an effective resolution on imposition of an administrative penalty on a controlled person for committing an administrative offense in the field of education for a period of 3 years preceding the date of the decision to classify the object of federal state control (supervision) in the field of education as the certain risk categories;

4) high risk category - educational activities of controlled persons with the simultaneous presence of the criteria specified in paragraphs 2 and 3 of this section.

\section{Discussion of Results}

The study showed that the current Model does not fully take into account all the risks of damage to legally protected interests in the field of education, does not fully contain the necessary assessment criteria, mechanisms, methods of control and supervision over the field of education.

The experience of control and supervision activities in the Republic of Kazakhstan has been studied.

The objects of state control in the field of education are:

- educational activities of legal entities carrying out educational activities;

- the level of mastering by students of the relevant educational programs.

The main types of state control in the field of education in the Republic of Kazakhstan are:

- state certification of educational organizations. State attestation is carried out according to the same principles and forms as state accreditation in Russia; 
- control over compliance with the legislation of the Republic of Kazakhstan on education and qualification requirements for educational activities. State control is carried out in the form of inspections and preventive control.

Russian and Kazakh legislation is similar in terms of self-assessment by educational organizations: they are obliged to conduct self-assessment annually and submit an appropriate report to the state educational authorities.

The criteria for assessing the degree of risk are divided into objective and subjective. Objective risk assessment criteria are those that do not depend on the activities of the subject of control. Subjective risk assessment criteria are the result of the activity of a specific subject of control.

The objective criteria of the subject of control are divided into two degrees: high and not classified as high. A high degree of risk includes educational organizations that implement programs in accordance with state educational standards.

The group that is not classified as high includes other educational organizations, incl. implementing additional education. In relation to these subjects, unscheduled inspections and preventive control are carried out without visiting the subject of control.

For the assessment of subjective criteria, violations in the field of education legislation are important, which are divided into: gross, significant and insignificant.

Violations of the legislation in the field of education in terms of the organization of the educational process are considered insignificant.

Violations of legislation in the field of education in terms of creating conditions for implementation of the educational process are considered significant.

Gross violations include violations that entail a decrease in the quality of education, non-compliance with notification requirements and qualification requirements for the teaching staff.

\section{Conclusions}

Based on the results of the study, it is offered to improve the risk-oriented approach model, when arranging control and supervisory activities in the field of education. The criteria for correlating educational organizations are offered to be classified into subjective and objective [8].

Objective criteria include the following indicators:

- type of educational organization. This categorization is explained by the complexity and significance of the implemented programs for the economy, social field and other state interests;

- the average annual number of students. This categorization is explained by the scale of possible damage to legally protected values by unlawful actions of the subjects of control. To calculate the risk category, it is offered to assign a specific one to each type of educational organization. For example, educational organizations that carry out educational activities as the main type of activity for implementation of educational programs for preschool education, supervision and care of children $-\mathrm{k}=1.0(\mathrm{Ol})$; organizations carrying out on the basis of licensing, along with the main activity, an additional type of activity - educational activity $-\mathrm{k}=0.7(\mathrm{Ol})$.

To determine the coefficient, educational organizations can be further divided into subtypes, and a more subtle differentiation of their risks can be carried out [9]. For example, separate into a separate subgroup:

- educational organizations - clusters that implement all levels of education or some of them (preschool, general, secondary vocational, higher, and etc.);

- professional educational organizations that implement educational programs of secondary vocational education in the areas of defense, production of products for defense orders, 
internal troops, activities of the National Guard of the Russian Federation, security, nuclear energy, transport and communications, science-intensive production in specialties, the list of which is approved by the Government of the Russian Federation;

- educational activities of Russian organizations carrying out educational activities abroad and others.

It is offered to differentiate educational organizations by the average number of students, with the assignment of appropriate coefficients (O2). For example, less than 1000 students - $\mathrm{k}=0.5(\mathrm{O} 2)$, over 5000 students $-\mathrm{k}=1.0(\mathrm{O} 2)$

Thus, the final objective criterion will be formed according to the formula: $\boldsymbol{P 1}=\boldsymbol{O} 1 \mathrm{x}$ O2, where

It is offered to include the following indicators as subjective criteria:

- the presence of well-grounded and confirmed appeals (complaints, statements) (P3);

- availability of an independent assessment of the quality of education, public or professional and public accreditation, an independent assessment of qualifications (P2);

- bringing to administrative responsibility for the last three years for violations in the field of education $(\boldsymbol{P 4})$.

- the results of monitoring observations of the educational organization (R5).

To calculate the risk category, each subjective indicator is offered to assign its own decreasing or increasing coefficient, but taking into account the type of educational organization:

In presence of substantiated and confirmed appeals (complaints, statements) for all types of educational organizations, an increasing coefficient of $\boldsymbol{P 3}-1.5$ is set.

In the presence of an independent assessment of the quality of education, public or professional and public accreditation, an independent assessment of qualifications [6], a reduction factor is set: from 1.0 to 0.5 .

If educational organizations are brought to administrative responsibility on the indicated grounds, an increasing coefficient of $\boldsymbol{P} 4$ is set at 1.5.

To take into account the results of previous inspections by the control and supervisory authorities, when establishing the risk category, it is offered to combine typical violations by groups [7] and assign them an appropriate score, depending on their complexity and severity (from 10 to 100 ).

To determine the risk category, the total number of points is calculated using the usual arithmetic addition (coefficient $\boldsymbol{P 5}$ ). Calculations can be made using two methods:

1) a set of violations of the same type is assigned an appropriate score;

2) each violation is assigned a score based on the type of violation. In this case, the total number of points for violations will be more than 760 .

The choice of methodology is the right of the control and supervisory authority, which must adopt the appropriate regulatory legal act.

To determine the risk category depending on the number of violations identified as a result of the previous inspection, the risk coefficient depending on the scores shall be determined (calculation according to the first method):

- less than 400 points - coefficient P5 - 0.5;

- 401 - 600 points $-\boldsymbol{P 5}$ coefficient - 1.0;

- more than 600 points - coefficient P5 - 1.5.

When determining the category of risk of causing harm to the values protected by law, in order to implement a risk-oriented approach to control and supervision in the field of education, it is recommended to use monitoring indicators calculated according to the specified methods. Each of these indicators has its own percentage to the average indicator or to the statutory minimum (maximum) indicator. To calculate the average, it is offered to calculate a certain average percentage by calculation. The calculation methodology shall be developed in terms of indicators and levels of education. 
For example, the indicator "The proportion of the number of people with a doctorate in the total number of teaching staff of educational institutions implementing higher education programs" is $5 \%$, the average for Russia is $10 \%$, the ratio is $50 \%$. The indicator "The proportion of the number of persons under the age of 30 in the total number of teaching staff of educational institutions implementing higher education programs" is $30 \%$, the average for Russia is $50 \%$, the ratio is $60 \%$.

The average indicator is calculated using the usual arithmetic method: $(50+60): 2=$ $55 \%$. Other indicators are taken into account in the same way.

To determine the category of risk of harm for the purpose of a risk-based approach to control and supervisory activities, it is recommended to determine the coefficient depending on the final average indicator for monitoring (M1).

The average monitoring indicator is less than $50 \%$ - coefficient is 1.5 ;

Average monitoring indicator $51-80 \%$ - coefficient 1.2;

Average monitoring indicator 81 - 99\% - coefficient 1.0;

Average monitoring indicator $100 \%$ or more - coefficient 0.5 .

To calculate the risk category $(\boldsymbol{R C})$, it is necessary to calculate according to the following formula: $\boldsymbol{R C}=P 1 \times P 2 \times P 3 \times P 4 \times M 1 \times P 5$.

The ratio of risk coefficients between minimum and maximum will allow for a more differentiated attribution of educational organizations to one or another risk category.

The offered differentiated calculation of risk categories of educational organizations can be used to determine the types of control (supervisory) measures, including preventive ones.

The model offered by the authors of the study will make it possible to more accurately differentiate educational organizations when determining their risk category of causing damage to legally protected interests in order to implement a risk-oriented approach to the control and supervisory function.

Therefore, according to the results of the study, it shall be concluded that the current model of a risk-oriented approach to arranging the control and supervisory activities in the field of education has directions for further improvement:

1. Expansion of objects of state control (supervision) by including in the scope of attention of control and supervisory bodies the activities of organizations for provision of educational services in electronic form and (or) using distance educational technologies in social networks, special mobile applications, and etc.

2. Expansion of tools for state control (supervision) through use of large data arrays (Big Data) and introduction of management mechanisms based on big data [10].

3. More fine tuning in the categorization of educational organizations and a gradual transition from three categories to a larger number of categories, taking into account the peculiarities of implementation of educational activities.

4. Criteria for categorizing risk are extremely generalized and require further elaboration and detailing; do not take into account the peculiarities of the implementation of various types of educational activities and allow a significant part of educational organizations to be in a low risk category, in fact, leaving the orbit of attention of control and supervisory authorities.

5. A separate study will require a mechanism for monitoring compliance with mandatory requirements (security monitoring), the experience of its enforcement and assessment of its effectiveness.

6. Development of alternative, non-state methods and methods of control in the field of education. 


\section{References}

1. Bazovaya model' opredeleniya kriteriev i kategorij riska, utv. protokolom zasedaniya proektnogo komiteta ot 31.03.2017, 19(3). Access mode: https://online.consultant.ru

2. N. V. Makarejko, Risk-orientirovannyj podhod pri osushchestvlenii kontrolya $i$ nadzora, Yuridicheskaya tekhnika, 13, 225-229 (2019)

3. Pis'mo Rosobrnadzora «O napravlenii metodicheskih rekomendacij po otboru obrazovatel'nyh organizacij dlya vklyucheniya $\mathrm{v}$ ezhegodnyj plan provedeniya planovyh proverok», 02-343 (2016). Access mode: https://online.consultant.ru

4. E. Z. Sidorova, Risk-orientirovannyj podhod v obrazovatel'noj srede kak prioritetnoe napravlenie razvitiya obrazovaniya, Podgotovka kadrov dlya silovyh struktur: sovremennye napravleniya i obrazovatel'nye tekhnologii, XXIV Vserossijskaya nauchno-metodicheskaya konferenciya, 49-52 (2019)

5. V. A. Kunin, I. V. Uporova, Risk-orientirovannyj podhod kontrol'no-nadzornoj deyatel'nosti: mezhdunarodnyj opyt i osobennosti primeneniya $v$ Rossijskih usloviyah, Ekonomika i upravlenie, 2 (160), 59-68 (2019)

6. Y.A. Svirin, S.E. Titor, A.A. Petrov, E.A. Morozova, O.Y. Scherbakova, Practiceoriented model of professional education in Russia, International Journal of Environmental and Science Educationthis link is disabled, 11(15), 7368-7380 (2016)

7. Tipichnye narusheniya zakonodatel'stva $\mathrm{v}$ sfere obrazovaniya po itogam kontrol'nonadzornyh meropriyatij. Access mode: http://mosobrnadzor.ru/files/files/metodics/Metodicheskiy_sbornik_typovye_narusheni ya.docx

8. M. C. M. Ehren, M. E. Honingh, Risk-based school inspections in the Netherlands: A critical reflection on intended effects and causal mechanisms, Studies in Educational Evaluation, 37 (4), 239-248 (2011)

9. D. Sherens, H. V. K. G. van Amel'svort, S. Donohyu, Aspects of the organizational and political context of school evaluation in four European countries, Studies in Educational Evaluation, 25(2), 79-108 (1999)

10. H. Gärtner, H. A. Pant, How valid are school inspections? Problems and strategies for validating processes and results, Studies in educational evaluation, 37, 85-93 (2011) 